w.babik@uj.edu.pl

Wydział Zarządzania i Komunikacji Społecznej

Uniwersytet Jagielloński

\title{
Ekologia informacji w bibliotecznej społeczności informacyjnej
}

\begin{abstract}
In a society based on the knowledge development the quickly and efficacious transfer and gathering of information is needed. The information ecology can contribute to optimization of this process. Information ecology is a field of research that concerns mutual interactions between man and information, as well as the information relationships existing among people in public and private information spaces. It is a practical activity, too. The aim of the paper is to define the place of information ecology in the creating process of information society and to explain the role of academic library in this process.
\end{abstract}

Słowa kluczowe: społeczeństwo wiedzy, ekologia informacji, biblioteka akademicka, społeczność informacyjna

\section{Wprowadzenie}

Społeczeństwo informacyjne opiera się na informacji i wiedzy oraz rozwoju nauki, w którym niezbędny jest szybki przepływ informacji, jej gromadzenie i skuteczne przetwarzanie. Do optymalizacji tego procesu może przyczynić się ekologia informacji. Jest to domena badawcza dotycząca wzajemnych oddziaływań człowieka na informację i odwrotnie, a także relacji informacyjnych między ludźmi w publicznej i prywatnej przestrzeni informacyjnej oraz wpływu na nie środowiska informacyjnego. Służy temu praktyczna działalność infoekologiczna. Celem artykułu jest określenie roli ekologii informacji $\mathrm{w}$ procesie tworzenia społeczeństwa wiedzy, $\mathrm{w}$ tym $\mathrm{w}$ działalności biblioteki akademickiej i bibliotecznej społeczności informacyjnej.

\section{Biblioteczna społeczność informacyjna}

Społeczeństwo informacyjne, które tworzymy w XXI w. jest „[...] nakierowane na zdobywanie informacji, operowanie informacją, przesyłanie informacji i inne aktywności wykorzystujące technologie elektroniczne [...]"1. Wprawdzie jego genezę wiąże się z przełomem XX i XXI w., ale można

${ }^{1}$ S. Kurek-Kokocińska, Społeczeństwo biblioteczne jako społeczeństwo informacyjne, „Zagadnienia Informacji Naukowej” 2001, nr 2 (78), s. 43. 


\section{0}

doszukiwać się jej w istniejącym od wielu wieków bibliotecznym społeczeństwie informacyjnym. Informacja jako tworzywo wiedzy istnieje bowiem od dawna w bibliotekach, które słusznie są nazywane skarbnicą wiedzy. Pracują w nich bibliotekarze, a korzystają z nich czytelnicy coraz częściej nazywani klientami. Obecne społeczeństwo, w którym przekształca się informacje w wiedzę w sposób produkcyjny, charakteryzują takie terminy, jak: fragmentaryzacja, konsumpcjonizm, konkurencyjność, niepewność, deregulacje zastanego ładu. Pod naporem informacji biblioteki współtworzą obecne oblicze społeczeństwa informacyjnego. Uzasadnia to użycie terminu biblioteczna społeczność informacyjna, obejmującego swoim zakresem zarówno bibliotekarzy zainteresowanych doskonaleniem obiegu informacji i wiedzy, gromadzących w tym celu źródła informacji oraz tworzących z zamiarem zapewnienia lepszej dostępności do nich zasoby metainformacyjne, między innymi w postaci katalogów bibliotecznych oraz użytkowników/czytelników bibliotek, którzy są konsumentami zgromadzonych $\mathrm{w}$ tych źródłach informacji i wiedzy. Od wszystkich członków tej społeczności między innymi ze względu na niezbędność poczucia bezpieczeństwa informacyjnego wymaga się permanentnego dokształcania się, gotowości do podejmowania nowych wyzwań, odpowiedzialności za informacje oraz ciągłego doskonalenia swoich kompetencji informacyjnych. Zilustrowano to na rys. 1 .

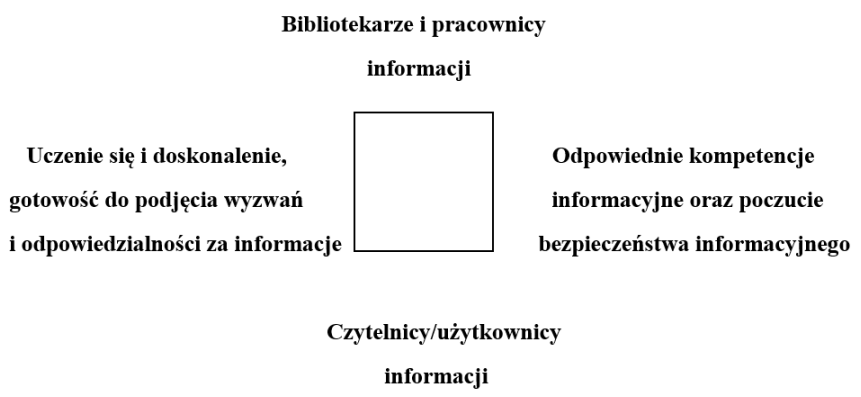

Rys. 1. Biblioteczna społeczność informacyjna

Źródło: Opracowanie własne.

Biblioteka i jej środowisko wpisuje się więc wyraźnie w koncepcję społeczeństwa informacyjnego jako kompetentny organizator procesów informacyjnych. Trzeba mieć jednak na uwadze, że w społeczeństwie informacyjnym „postęp techniczny czyni, że przepływ informacji cechuje chwilowość i natychmiastowe zaspokojenie ciekawości, a nawet wytworzenie relacji emocjonalnych. Szybkiemu przepływowi informacji nie towarzyszy refleksja poznawcza 
porządkująca wiedzę, a nierzadko i sens. Ten styl działania informacji społecznej przenosi się na postawy i zachowania społeczne"2. Stale podnoszony w bibliotekach komfort pracy użytkownika staje się czasem powodem frustracji, stąd niezbędne jest - jak zauważa to Stanisława Kurek-Kokocińska ${ }^{3}$ zwracanie uwagi na oddziaływania informacji w społeczności informacyjnej, czyli dostrzeżenie społecznego kontekstu ilościowo zwielokrotnionej i zróżnicowanej tematycznie podaży informacji. Zasygnalizowana tu optyka spojrzenia na biblioteczną społeczność informacyjną wymaga wsparcia w postaci rozważań infoekologicznych.

\section{Ekologia informacji - pojęcie i problematyka}

Ekologia informacji jest uważana - obok architektury informacji - za jedną z najnowszych specjalności nauk humanistycznych, w tym nauk informacyjnych (nauki o informacji), „Zaczęła się rozwijać pod naporem i przeciw dominacji technologicznych aspektów projektowania i eksploatacji systemów informacyjnych $\mathrm{w}$ rozległych sieciach komputerowych na przełomie $\mathrm{XX}$ i XXI w."

\section{Ekologia informacji to metafora}

Termin „ekologia informacji” jest metaforą, która w biologicznym i przyrodniczym rozumieniu traktuje przyrodę (ekosferę) jako system złożony z elementów ożywionych i nieożywionych oraz reakcji między nimi. W ekologii informacji analogicznie do ekologii (przyrody) są to ludzie, użytkownicy informacji, technologie oraz interakcje między nimi. Ekologiczne analogie narzucają też zjawiska związane z gwałtownym i nieuporządkowanym przyrostem informacji, które Ryszard Tadeusiewicz nazywa zalewem informacji, mgłą i smogiem informacyjnym ${ }^{5}$.

Dla ekologii informacji ekosystem/infosystem staje się przestrzenią informacyjną ${ }^{6}$. Termin ten wyraża związek między ideami ekologii środowiska przyrodniczego a dynamicznie rozwijającą się cyfrową przestrzenią informacji.

${ }^{2}$ A. Chodubski, Informacja $w$ warunkach ksztattujacej się globalnej społeczności obywatelskiej, [w:] Informacja naukowa a dydaktyka: międzynarodowa konferencja $w$ Wojewódzkiej Bibliotece Publicznej, Gdańsk 10-12 czerwca 1999. Red. meryt. M. Drzewiecki, J. Puchalski, przy współpr. A. Malewskiej, B. Sosińskiej-Kalaty, M. Zająca. Warszawa, s. 40.

${ }^{3}$ S. Kurek-Kokocińska, op.cit.

${ }^{4}$ A. Sitarska, Systemowe badania bibliotek: studium metodologiczne, Białystok 2005, s. 16.

${ }^{5} \mathrm{R}$. Tadeusiewicz, $W$ dymie $i$ we mgle, [dostęp: 20.05.2015], http://www.solidarnosc. org.pl/ ksn/Docs/rystad.pdf.

${ }^{6}$ B. Nardi, V.L. O'Day, Information Ecologies. Using Technology with Heart, Cambridge 1999, $246 \mathrm{p}$. 
W opisie i analizie środowiska informacyjnego, w tym systemów informacyjnych, ekologia informacji posługuje się językiem ekologii jako nauki przyrodniczej.

Ekologia informacji to koncepcja badawcza postulująca badanie procesów informacyjnych (gromadzenia, opracowywania i udostępniania informacji) w sposób analogiczny do badań procesów ekologicznych. Badania te dotyczą przede wszystkim czynników wpływających na stan środowiska informacyjnego człowieka (antropoinfosferę). Jednym $\mathrm{z}$ elementów tego środowiska jest biblioteczna społeczność informacyjna. Nadmiar informacji, przejawiający się m.in. w przeciążeniu informacyjnym, jest jedną z przyczyn ekologicznego kryzysu informacyjnego, będącego między innymi skutkiem niezrównoważonego rozwoju różnych sfer człowieka: intelektualnej, wolitywnej, afektywnej i innych $^{7}$. Ekologia informacji upatruje przyczyn tego kryzysu w niezrównoważonym rozwoju tego środowiska, przejawiającym się w zachwianiu właściwych proporcji (równowagi) pomiędzy czynnikami wywołującymi i sterującymi ten rozwój.

Na pojęcie ekologii informacji składa się wiele oddziałujących na siebie i wzajemnie zależnych podsystemów społecznych, kulturowych i politycznych oraz technologicznych, które wpływają na procesy tworzenia, przepływu i wykorzystywania informacji.

Ekologia informacji jako taka jest kojarzona z ideami i pracami Rafaela Capurro, Thomasa Davenporta i Laurence'a Prusaka oraz Aleksieja Eryomina, którzy o ekologii informacji pisali już w latach siedemdziesiątych XX w.

Panowanie nad informacją i środowiskiem informacyjnym (jego stanem) jest powszechnie postrzegane jako zjawisko naturalne, w przeciwieństwie do dominacji informacji nad człowiekiem, co następuje w okresie wspomnianego ekologicznego kryzysu informacyjnego. Ekologia informacji proponuje wizję funkcjonowania człowieka i społeczeństwa $\mathrm{w}$ harmonii $\mathrm{z}$ jego naturalnym środowiskiem informacyjnym (ekosystemem), to jest takim, które jest dostosowane do jego naturalnych możliwości. Dzięki temu pojawia się szansa niwelowania rozdarcia między naturalnym stanem antropoinfosfery a sztuczną i nienaturalną produkcją w środowisku człowieka informacji, w tym szaleńczym wytwarzaniem i publikowaniem dużych ilości śmieci informacyjnych, powodujących zanieczyszczenie tego środowiska i choroby informacyjne.

Badania z tego zakresu są prowadzone od początku lat pięćdziesiątych XX w. w USA i w Europie Zachodniej, a także w ZSRR. Za prekursorów ekologii informacji można uznać między innymi Alvina Tofflera (Szok przysztości, wyd. ang. 1970), Juliusza Lecha Kulikowskiego (Informacja i świat, w którym żyjemy, Warszawa 1978) oraz Neila Postmana (Technopol. Tryumf techniki nad kultura, wyd. ang. w roku 1992) ${ }^{8}$.

\footnotetext{
${ }^{7} \mathrm{~W}$. Babik, O nattoku informacji i związanym z nim przeciązeniu informacyjnym, [dostęp: 20.05.2015], http://www.ap.krakow.pl/ktime/ref2010/babik.pdf.

${ }^{8}$ W. Babik, Ekologia informacji, Kraków 2014.
} 
Twórcami/pionierami ekologii informacji są już wspomniani Thomas Davenport i Laurence Prusak oraz Aleksiej Eryomin. Koncepcja Davenporta i Prusaka akcentuje związek między ekologią informacji a zarządzaniem informacją, które określają jako holistyczne zarządzanie informacją lub skoncentrowane na człowieku zarządzanie informacją. Twierdzą, że informacja i wiedza są wytworami typowo ludzkimi i nigdy nie będą dobrze zarządzane, jeśli priorytetu $\mathrm{w}$ tych działaniach nie przyzna się człowiekowi. Esencję tego podejścia stanowi przywrócenie człowiekowi należnego mu miejsca w centrum świata informacji i próba skierowania technologii na peryferie, na swego rodzaju banicję 9 .

Za granicą to pole badawcze eksplorują także Rafael Capurro, Hochschule der Medien in Stuttgart (Niemcy) ${ }^{10}$ i Jela Steinerova z Departament of Library and Information Science, Comenius University Bratislava (Slovakia) ${ }^{11}$. W Polsce ekologią informacji zajmuje się stosunkowo niewielkie grono badaczy, których część konsekwentnie używa terminu ekologia informacji; pozostali $\mathrm{z}$ różnych powodów nie posługują się tym terminem.

\section{Przedmiot i zakres ekologii informacji}

Ekologia informacji to pole badawcze nauki o informacji oznaczające „Sumę ocen jakości, zarządzania, produktów i wartości informacji, jak również ocenę usług i potrzeb informacyjnych. (...) to dyscyplina wiedzy, której zadaniem jest odkrywanie praw rządzących przepływem informacji w biosystemach, włącznie z człowiekiem, społeczeństwem, ich wpływem na zdrowie psychiczne, fizyczne i społeczne ludzi oraz rozwijanie odpowiednich metodologii mających na celu kształtowanie środowiska informacyjnego" ${ }^{\prime 2}$.

Przedmiotem ekologii informacji są między innymi:

- $\quad$ kryteria jakościowe i ilościowe informacji;

- relacje pomiędzy informacją a zdrowiem człowieka;

- $\quad$ wartość informacji;

- $\quad$ procesy przekazywania i recepcji informacji;

- jakość usług informacyjnych;

- $\quad$ odpowiedzialność za informacje i jej skutki społeczne;

\footnotetext{
${ }^{9}$ T. Davenport, L. Prusak, Information Ecology. Mastering Informational Knowledge Environment, New York 1997, 272 s.

${ }^{10}$ R. Capurro, Towards an Information Ecology, [in:] Information and Quality. Proceedings of the NORDINFO International Seminar, Copenhagen. August 23-25.1989, London 1990, pp. 122-139.

${ }^{11}$ J. Steinerová, Information Ecology - Emerging Framework for Digital Scholarship, [in:] Libraries in the Digital Age (LIDA). Proceedings, 2012, vol. 12 (2012), [dostęp: 20.05.2015], http://ozk.unizd.hr/proceedings/ index.php/../66/37

${ }^{12}$ A.L. Eryomin, Information Ecology - a Viewpoint, „International Journal of Environmental Studies: Sections A\&B” 1998, No 3/4, s. 251.
} 
- $\quad$ rozwój/ewolucja środowiska informacyjnego;

- $\quad$ zarządzanie informacją w pracy, domu, społeczeństwie ${ }^{13}$.

Praktycznym zadaniem ekologii informacji jest kształtowanie środowiska informacyjnego człowieka oraz ochrona naturaln ego środowiska informacyjnego człowieka, zagrożonego przede wszystkim przez nowoczesne technologie informacyjno-komunikacyjne. Środkami realizacji tego zadania są:

- dbanie o jakość informacji, gdyż niska jakość informacji negatywnie wpływa na człowieka. Dotyczy to przede wszystkim obszaru, który stanowi przestrzeń informacyjna rzeczywista i wirtualna;

- niedopuszczanie do generowania informacji, które nie spełniają norm jakościowych, stanowiąc swoistego rodzaju truciznę zanieczyszczającą środowisko informacyjne człowieka i społeczeństwa;

- $\quad$ usuwanie informacji, które trwale i całkowicie utraciły swoją użyteczność, a także utylizacja informacji, czyli przywracanie użyteczności informacjom, które się do tego nadają;

- dbanie o wartościowy, bezpieczny i dobrze zorganizowany dostęp do informacji i wiedzy, w tym usuwanie barier informacyjnych;

- $\quad$ inicjowanie działań mających na celu poprawę i usprawnienie funkcjonowania człowieka $\mathrm{w}$ tym środowisku, $\mathrm{w}$ tym badanie procesów percepcji i recepcji informacji;

- $\quad$ wprowadzanie stanu równowagi i harmonii w antropoinfosferze w celu zapewnienia zrównoważonego rozwoju człowieka w społeczeństwie informacji i wiedzy.

Równoważenie rozwoju społeczeństwa informacji i wiedzy to reakcja na zespół zagrożeń wynikających $\mathrm{z}$ niekontrolowanego generowania informacji oraz wiedzy i ich negatywnego wpływu na człowieka. Zrównoważony rozwój to taki rozwój, który nie zakłóca naturalnych eko(info)systemów tworzących antropoinfosferę, w której funkcjonuje człowiek.

Realizacja zadań ekologii informacji znajduje wyraz w następujących kierunkach badań naukowych:

- $\quad$ badanie relacji pomiędzy informacją a zdrowiem człowieka;

- badanie potrzeb informacyjnych;

- identyfikowanie kryteriów ilościowych i jakościowych informacji;

- badanie wartości informacji;

- badanie metod przechowywania i dostępu do informacji;

- $\quad$ badanie procesów przekazywania i recepcji informacji;

- badanie relewancji;

- ocena jakości usług informacyjnych;

- określanie odpowiedzialności za informację i jej skutki społeczne;

- $\quad$ zarządzanie informacją w miejscu pracy, organizacjach, społeczeństwie.

${ }^{13}$ W. Babik, Ekologia informacji, „Zagadnienia Informacji Naukowej” 2001, nr 2 (78), s. 64-70; idem, Ekologia informacji - wyzwanie XXI wieku, „Praktyka i Teoria Informacji Naukowej i Technicznej” 2002, nr 1 (37), s. 20-25. 
W ekologii informacji można zidentyfikować również następujące nurty badawcze:

1. Ochrona środowiskowego dziedzictwa informacyjnego, kulturowego i cyfrowego, czyli ochrona samej informacji i jej jakości.

2. Dbałość i troska o odpowiednią prezentację informacji (i instytucji związanych z informacją) $w$ środowisku elektronicznym.

3. Ochrona człowieka przed nadmiernym i negatywnym wpływem toksycznych informacji.

4. Identyfikacja i ochrona więzi informacyjnych w środowisku twórców i użytkowników informacji.

5. Równoważenie aspektów społecznych i technologicznych w postrzeganiu przestrzeni informacyjnej.

Na kanwie tych kierunków powstały następujące koncepcje ekologii informacji:

1. Pragmatyczna koncepcja ekologii informacji R. Capurro (1989).

2. Organizacyjna koncepcja ekologii informacji T. Davenporta i L. Prusaka (1997).

3. Koncepcja ekologii informacji A. Eryomina (1998).

4. Aksjologiczna koncepcja ekologii informacji B.A. Nardi i V.L. O’Day (1999).

5. Etyczna koncepcja ekologii informacji L. Floridi (2002).

Aktualnie obszar badań ekologii informacji to potrzeby informacyjne użytkowników, zachowania informacyjne użytkowników informacji oraz bariery informacyjne w dostępie do informacji. Stąd rodzą się ekologie poszczególnych obszarów.

Praktyczne działania ekologii informacji to:

- działania zmierzające do zwiększenia świadomości informacyjnej człowieka jako podmiotu w procesach informacyjnych;

- $\quad$ ochrona człowieka przed jego uprzedmiotawianiem za pomocą informacji (manipulacje);

- rozwijanie kompetencji informacyjnych człowieka umożliwiających mu racjonalne zarządzanie informacją, panowanie nad nadmiarowością informacji, uniezależnianie się od niepożądanych wpływów informacji, zwłaszcza od manipulacji ludzkimi postawami i zachowaniami;

- edukacja do odpowiedzialności za tworzenie/generowanie, przetwarzanie, rozpowszechnianie i wykorzystywanie informacji;

- równoważenie rozwoju człowieka w świecie techniki, technologii i informacji. 


\section{Ekologia informacji wyzwaniem dla bibliotecznej społeczności informacyjnej}

Ekologia informacji to teoria nadbudowana nad działalnością praktyczną w sferze informacji. Działalność, o której tu mowa, to w interesie człowieka szeroko rozumiana ochrona informacji, między innymi przed różnego rodzaju zanieczyszczeniami, a więc dbałość o czystość informacji i radzenie sobie z jej nadmiarem. To oferta nowego spojrzenia na współczesne problemy informacyjne. Oprócz wiedzy o cechach i rodzajach informacji, o procesie informacyjnym, o potencjalnych zagrożeniach właściwego odbioru informacji, niezbędna jest odpowiednia kultura informacyjna i edukacja informacyjna zmierzająca do uświadomienia człowiekowi i społeczeństwu konieczności selekcji informacji na każdym z etapów jej obiegu.

Ekologia informacji wymaga wieloaspektowego podejścia do badanych problemów. Obecnie nie ma już jednej ekologii informacji. Są ekologie informacji, dotyczące różnych przedmiotów, instytucji, rzeczywistości, środowisk i zjawisk.

Rozwój technologii informacyjnych w niewielkim stopniu uwzględnia czynnik ludzki. Rodzi to rozmaite problemy. Ekologia informacji stara się przywrócić właściwe miejsce czynnikowi ludzkiemu, aby - jak zauważył Rafael Capurro - osiągnąc stan równowagi pomiędzy różnymi czynnikami, traktując każdą organizację jako złożoną z rozmaitych elementów - technologii, praktyk i ludzi ${ }^{14}$.

Naczelnym wyzwaniem ekologii informacji jest równoważenie rozwoju środowiska informacyjnego człowieka (antropoinfosfery), czyli próba wprowadzenia/powrotu naturalnej równowagi pomiędzy nadmiarem a deficytem (brakiem) informacji. Działania ekologiczne mają na celu zapobieganie anomaliom informacyjnym, dzięki czemu stają się katalizatorem rozwoju człowieka ${ }^{15}$.

Ekologia informacji kładzie szczególny nacisk na jakość i wiarygodność informacji, oszczędność przekazu, obecność metainformacji, czystość informacji i czystość przekazu.

Podejście ekologiczne cechuje się tym, że na każdym etapie tworzenia, przekazywania i odbioru informacji kierujemy się rzetelnością i oszczędnością informacji, unikamy manipulacji informacją, dbając w ten sposób o środowisko informacyjne odbiorcy. Ekologia informacji zamiast manipulowania informacją preferuje postępowanie zgodne z zasadami etyki informacyjnej, ograniczenie działań powodujących nieuzasadniony przyrost informacji (z wyjątkiem koniecznej redundancji przekazu) i przeciążenie informacyjne, uporządkowanie przekazu (materiału), sugeruje poprawny i atrakcyjny styl, wprowadzanie

\footnotetext{
${ }^{14}$ R. Capurro, op. cit.

${ }^{15}$ W. Babik, Ekologia informacji katalizatorem równoważenia rozwoju społeczeństw informacji $i$ wiedzy, „Zagadnienia Informacji Naukowej” 2012, nr 2 (100), s. 48-65.
} 
metainformacji i odesłań kontekstowych, co ma prowadzić do równoważenia procesów tworzenia, przekazu i odbioru informacji oraz odpowiedniej dla odbiorcy organizacji treści, a także odpowiedniej i atrakcyjnej formy przekazu.

Powinniśmy zdawać sobie sprawę z tego, że współczesny odbiorca informacji jest mocno zapośredniczony w świecie elektronicznym, szczególnie w Internecie, stąd nie można bagatelizować jego nawyków i potrzeb w tym środowisku. Oznacza to, że ze względu na ekonomię uwagi, ograniczoną pojemność pamięci człowieka oraz zjawisko nadmiaru informacji, należy zmierzać w kierunku tworzenia krótkich i treściwych tekstów komunikatów.

W przypadku omawianego tematu wartość dodana ekologii informacji polega na zwróceniu uwagi na potrzebę wrażliwości ekologicznej i konieczność uwzględniania wszystkich elementów, które opisują specyfikę podejścia w ekologii informacji.

\section{Rola ekologii informacji w bibliotecznej społeczności informacyjnej}

Ekologia informacji proponuje wizję funkcjonowania człowieka i społeczeństwa $\mathrm{w}$ harmonii $\mathrm{z}$ jego/ich naturalnym środowiskiem informacyjnym, to jest takim, które jest dostosowane do naturalnych możliwości człowieka.

Zwraca uwagę na niepokojące rozdarcie w środowisku informacyjnym człowieka między sztuczną i nienaturalną produkcją/wytwarzaniem, w tym szaleńczym wytwarzaniem jak największych ilości śmieci informacyjnych, powodujących zanieczyszczenie tego środowiska i choroby informacyjne a naturalnym stanem antropoinfosfery. Proponuje jasne zasady tworzenie, rozpowszechniania i korzystania $\mathrm{z}$ informacji propagując zasadę równowagi informacyjnej odpowiadającej naturalnemu przekazowi informacji.

Ekologia informacji w bibliotecznej przestrzeni informacyjnej to:

- kształtowanie świadomości informacyjnej bibliotekarzy i czytelników/ użytkowników informacji bycia podmiotem w procesach informacyjnych;

- akcentowanie niezbędności posiadania przez te osoby odpowiednich kompetencji informacyjnych umożliwiających racjonalne zarządzanie informacją, panowanie nad nadmiarowością informacji, unikanie manipulacji za pomocą informacji ludzkimi postawami i zachowaniami;

- odpowiedzialność za tworzenie/generowanie, przetwarzanie, rozpowszechnianie i wykorzystywanie informacji;

- umiejętne wykorzystywanie informacji w budowaniu indywidualnej i zbiorowej wiedzy oraz tworzenie własnego indywidualnego środowiska informacyjnego.

Bibliotecznej społeczności informacyjnej ekologia informacji zwraca szczególną uwagę na potrzebę respektowania faktu ograniczonej pojemności ludzkiego mózgu i konsekwencje natłoku informacji; wagę jakości otoczenia informacyjnego/środowiska informacyjnego nadawcy i odbiorcy informacji; potencjalne niebezpieczeństwa $\mathrm{w}$ sferze informacji, a także formułuje zalecenia dotyczące równoważenia procesów informacyjnych. 


\section{Podsumowanie}

Ekologia informacji jest rodzajem działalności informacyjnej, w której współczesnemu człowiekowi i społeczeństwu zwraca się uwagę między innymi na potrzebę scalania pokawałkowanej informacji i wiedzy, konieczność edukacji $w$ zakresie tworzenia oraz korzystania $z$ informacji $i$ wiedzy (wartościowanie informacji), potrzebę (eko)kultury informacyjnej oraz niezbędność tworzenia i używania odpowiednich metod i narzędzi do filtrowania informacji ${ }^{16}$.

Ekologia informacji wychodzi naprzeciw współczesnym bolączkom szeroko pojętego procesu komunikowania się i oferuje rozwiązania sprzyjające optymalizacji tego procesu stosownie do potrzeb i możliwości bibliotecznej społeczności informacyjnej, może i powinna stać się jednym z elementów potencjału edukacyjnego współczesnego bibliotekarza i użytkownika informacji.

\section{Bibliografia}

Babik, W., Ekologia informacji, ,Zagadnienia Informacji Naukowej” 2001, nr 2 (78), s. 64-70.

Babik, W., Ekologia informacji - wyzwanie XXI wieku, ,Praktyka i Teoria Informacji Naukowej i Technicznej" 2002, nr 1 (37), s. 20-25.

Babik W., O natłoku informacji $i$ związanym z nim przecią̇eniu informacyjnym, [dostęp: 20.05.2015], http:/www.ap.krakow.pl/ktime/ref2010/babik.pdf.

Babik, W., Ekologia informacji katalizatorem równoważenia rozwoju społeczeństwa informacji $i$ wiedzy, „Zagadnienia Informacji Naukowej” 2012, nr 2 (100), s. 48-65.

Babik, W., Ekologia informacji, Kraków 2014.

Capurro, R., Towards an Information Ecology, [in:] Information and Quality. Proceedings of the NORDINFO International Seminar, Copenhagen. August 23-25. 1989, ed. I. Wormell, London 1990, pp. 122-139 + [dostęp: 20.05.2015], http://www.capurro.de/nordinf.htm.

Chodubski, A., Informacja w warunkach kształtującej się globalnej społeczności obywatelskiej, [w:] Informacja naukowa a dydaktyka: międzynarodowa konferencja $w$ Wojewódzkiej Bibliotece Publicznej, Gdańsk 10-12 czerwca 1999. Red. meryt. M. Drzewiecki, J. Puchalski, przy współpr. A. Malewskiej, B. Sosińskiej-Kalaty, M. Zająca. Warszawa 1999, s. $36-46$.

Davenport, T., Prusak, L., Information ecology. Mastering Informational Knowledge Environment. New York1997, 272 s.

Eryomin, A. L., Information ecology - a viewpoint, "The International Journal of Environmental Studies", 1998, vol. 54, pp. 241-253.

Kurek-Kokocińska, S., Społeczeństwo biblioteczne jako społeczeństwo informacyjne, „Zagadnienia Informacji Naukowej” 2001, nr 2 (78), s. 43-63.

Nardi, B., O’Day, V.L., Information Ecologies. Using Technology with Heart, Cambridge 1999,246 p.

Sitarska, A., Systemowe badania bibliotek: studium metodologiczne, Białystok 2005.

\footnotetext{
${ }^{16}$ W. Babik, Ekologia informacji katalizatorem równoważenia...; idem, Ekologia informacji, Kraków 2014.
} 
Steinerová, J., Information Ecology - Emerging Framework for Digital Scholarship, [in:] Libraries in the Digital Age (LIDA). Proceedings, vol. 12 (2012), [dostęp: 20.05.2015], http://ozk.unizd.hr/proceedings/index.php/../66/37.

Tadeusiewicz, R., $W$ dymie $i$ we mgle, [dostęp: 20.05.2015], http://www.solidarnosc.org.pl/ $\sim$ ksn/Docs/rystad.pdf. 